\title{
Findings on the Chiropteran Status in Rautahat and Sarlahi, Nepal
}

\author{
Sunny Kumar Jha ${ }^{1}$ \\ Email: sunny2savenature@gmail.com
}

\begin{abstract}
:
Bats are the second most diverse mammals found in earth with around 1250 species in a single Chiropteran order. In Nepal, authentic list of 53 bat species have been prepared so far. This research was conducted in 10 VDCs of Rautahat and Sarlahi with the main objectives being assessing the status, diversity and threats. Key-informant survey, direct observation, roost survey and mist netting were done for assessing the primary data. A total of five species were identified. Deforestation, poaching, destruction of old houses, concrete constructions, use of chemical fertilizers in agricultural and fruit lands, change in the agricultural pattern and deliberate killing were identified as major. People's attitude was satisfactory, though awareness level was found to be low. Diversity was found to be very high, but the respondents argued that the bats'frequency was in continuous decrease from past few years.
\end{abstract}

Key Words: Bats, Status, Threats, Species, Identification, Perceptions

\section{Introduction}

Bats (Chiroptera) are the second most diverse order of mammals, with about 1,250 species of bats worldwide (IUCN, 2011). The order Chiroptera has been divided into two Suborders, the Megachiroptera and the Microchiroptera. These were categorized on the basis of their specialization in feeding habitat and morphological adaptation (IUCN 2002). In South Asia alone, 17 species are endemic out of the total 123 species found. Among the total 1,250 species found, about $20 \%$ are threatened (IUCN, 2011). Although the bats are one of the largest groups of mammals, these are one of the least studied groups in the world. They are also the most relatively inconspicuous, only because they are active by night, hidden by day and wary of human contact (Malla, 2000).

Records show that 53 valid species are found in Nepal (Thapa, 2010). These species belong to seven different families viz. Pteropodidae, Rhinolophidae, Hipposideridae,

${ }^{1}$ President, Together For Nature, Nepal 
Megadermatidae, Emballonuroidae, Vespertilionidae and Miniopteridae. Other seven species also have possibility of being found as researched and reported by different researchers at different times (Thapa et al., 2010). Some 128 species of bats are known from South Asia (Srinivasulu et al., 2010), and the data obtained from Nepal represents about $5 \%$ of the world bat diversity and over $40 \%$ of South Asia's bat diversity. In recent studies, Thapa, 2010 has reported a new species Scotozonus dermani and Dahal, 2011 has reported Pipistrellus silonicus (unpublished). Hence, the number of the bat species is sure to increase owing to the research works being carried. Myers has already suggested a possibility of finding 86 bat species in Nepal in 2000. The study was conducted in Rautahat and Sarlahi districts of Nepal. Rautahat lies in $26^{\circ} 46^{\prime} \mathrm{N}$ latitude and $85^{\circ} 16^{\prime} \mathrm{E}$ longitude whereas Sarlahi lies in $26^{\circ} 51^{\prime} 20.56^{\prime \prime} \mathrm{N}$ latitude and $85^{\circ} 33^{\prime} 44.5^{\prime \prime} \mathrm{E}$ longitude. Both the districts lie in Central Nepal and have similar

geographic and natural attributes. These districts were selected as they are very rich in bat diversity and there has not been any research in about a century since the last one conducted by Bates and Harrison in 1923. The research was conducted with the objectives of assessing the bats' diversity in Sarlahi and Rautahat districts along the Bagmati River and the threats posed to them.

\section{Materials and Methodology}

Data were collected through direct observation, mist netting and key-informant survey. Research was carried by;

Key-informant Survey: Key- informant survey was done in the study area prior to actual research. Local inhabitants of the area, specially, the old people, teachers and local environmentalists were contacted as key informers. Based upon the information obtained, probable sites were short listed. Questionnaire included general questions about the respondents' knowledge and perceptions about bats. Threats were also assessed through the survey.

Direct Observation: To find out the presence or absence of the bats, direct observation was done in the probable sites. The probable sites were identified from key-informant survey. Each site was visited 2-3 times depending upon the ease of data collection and bat richness. During the observation, bat colonies and threats to them were identified.

Mist Netting: Mist netting was done to capture bats and to identify the species. This method has been recommended for Chiroptera assessment and is extensively used in species assessment. Where more than one species is present, this method can be used to determine relative abundance. 


\section{Data Analysis}

Data obtained from the key-informant survey were analyzed using Microsoft Excel and SPSS (Statistical Package for Social Sciences) version 16. Measurements were tallied and checked using Bats of Nepal, a field guide published by SMCRF. For further identification of bats, records were also sent to the bat specialists. Attitude and Perceptions were measured in 3 point and 5 point Likert scale.

\section{Result and Discussion}

\section{Identification of Bat Species}

For the measurements and proper identification, Bats of Nepal, A field guide, by SMCRF, Nepal was strictly followed. Using these measurements as basis, following measurements were taken to identify the bats in field:

\begin{tabular}{|l|l|l|l|l|l|l|l|l|l|}
\hline Species Found & HB & HF & FL & E & 5mt & 4mt & 3mt & T & Found in \\
\hline $\begin{array}{l}\text { Pteropus } \\
\text { giganteus }\end{array}$ & 245.5 & 46.2 & 162 & 38 & & & & & Trees \\
\hline $\begin{array}{l}\text { Scotophilus } \\
\text { heathii }\end{array}$ & 72 & 12 & 57.2 & 16 & 52.1 & 56.2 & 53.9 & 57 & Old Houses \\
\hline $\begin{array}{l}\text { Pipistrellus } \\
\text { coromandra }\end{array}$ & 37.4 & 4.3 & 27.8 & 9.2 & 28.1 & 26.4 & 27.1 & 25 & $\begin{array}{l}\text { Bamboo, bamboo } \\
\text { houses }\end{array}$ \\
\hline $\begin{array}{l}\text { Pipistrellus } \\
\text { tenuis }\end{array}$ & 38.6 & 5.6 & 27.7 & 7 & & & & 25 & $\begin{array}{l}\text { Bamboo, bamboo } \\
\text { houses }\end{array}$ \\
\hline $\begin{array}{l}\text { Cynopterus } \\
\text { sphinx }\end{array}$ & 98.6 & 15.7 & 69.3 & 19 & 46.3 & 43.6 & 48.4 & 8.8 & $\begin{array}{l}\text { Near to the fruit } \\
\text { farms }\end{array}$ \\
\hline
\end{tabular}

HB-Head Body Length, T-Tail Length, HF- Head Forearm length, FL- Forearm Length, E-Ear Length, 5mt- Fifth Metacarpal, 4mt- Fourth Metacarpal, 3mt- Third Metacarpal.

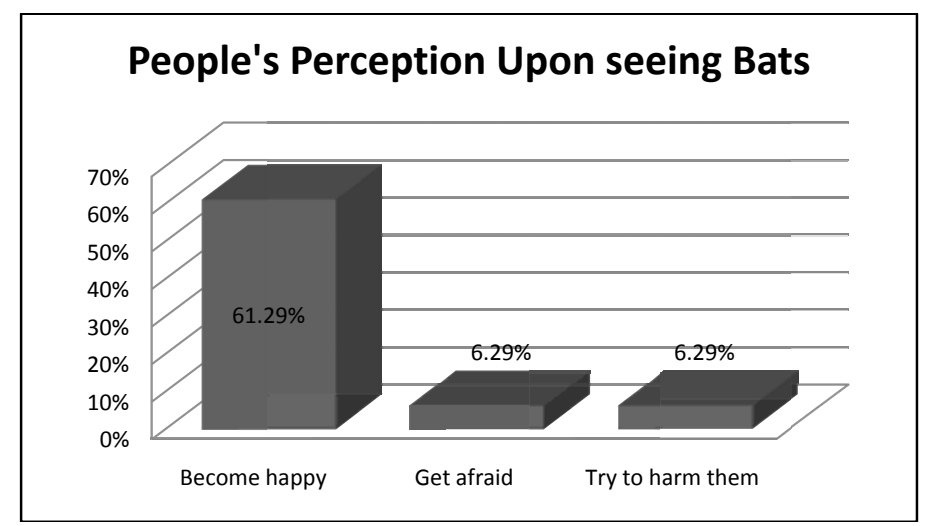

Figure 1: People's Perception towards Bats 
Majority of the people responded that they become happy upon seeing bats. $6.29 \%$ told that they got afraid and another 6.29\% responded that they try to harm bats upon seeing them. Surprisingly, highly educated people and even teachers were among those who tried to harm bats.

\section{Abundance of Bats in the Study Area}

All the respondents had seen bats in the area which confirmed their high abundance in the study area. 90.32\% responded having seen bats in the evening time, whereas $6.45 \%$ had seen them in the afternoon and 3.23\% had seen in the morning time. 93.54\% had seen them both singly and in groups. 3.23\% had seen them only singly and another $3.23 \%$ had seen them only in group. When asked about the color of the bats seen, $70.97 \%$ responded that they had seen black bats and $29.03 \%$ had seen both black and brown bats. . Despite the common occurrence of bats in the area, $96.77 \%$ responded that frequency of bats' occurrence had decreased over time.High abundance was also confirmed from direct roost and guano observations.

\section{Major Threats to Bats}

Habitat Destruction: Habitat destruction was the major threats to the bats. Deforestation is very high in Terai and the study area is no exception. Rampant falling of the trees has decreased the habitat availability of bats. Apart from deforestation, rapid conversion of the orchards to the housing plots has also caused habitat destruction.

Chemicals' use in Fruit Orchards: For the quick fruits' production and to get rid of the pests and insects, farmers use chemicals in their orchards. Since bats are either fruit eating or insect eating, they get affected by the use of such chemicals.

Hunting and Poaching: People kill bats due to three main reasons. Firstly, they consider bats as bad omen, and so whenever bats are in the sight, people kill them. Secondly, they kill bats as they think bats damage their fruits and finally, bats, especially, the Pteropus species have excellent market rate.

Apart from these common threats, few species had some specific threats.

\begin{tabular}{|l|l|l|}
\hline \multicolumn{1}{|c|}{ S.N. } & \multicolumn{1}{|c|}{ Species } & \multicolumn{1}{c|}{ Threats Identified } \\
\hline 1. & Pteropus giganteus & $\begin{array}{l}\text { Deforestation, Usage of chemicals in fruit farms, } \\
\text { Poaching, High Market Rate (NRs.30 per pair) }\end{array}$ \\
\hline 2. & Scotophilus heathii & Destruction of Old Houses \\
\hline 3. & Cynopterus sphinx & Usage of Chemicals, Decrease in Banana Farming \\
\hline 4. & Pipistrellus species & $\begin{array}{l}\text { Children play with them and unintentionally harm them, } \\
\text { bamboo houses being replaced by concrete constructions }\end{array}$ \\
\hline
\end{tabular}




\section{Conclusion}

The study area was found to be very rich in Chiropteran diversity. Bats' frequency was too high and very encouraging. Despite that, people still considered bats as bad omen and killed them mercilessly. Deforestation, destruction of old houses, usage of different chemicals in agricultural practices, change in the farming system, poaching and construction of concrete buildings were the major threats to bats.

\section{Reference}

Bates, P.J.J. and Harrison, D. 1997.Bats of the Indian Subcontinent. Harrison Zoological Museum, Sevenoaks,UK. (RIn).

Chaudhary, A. 2011. Species Identificaion \& Local People's Perception Towards Bat. A case study from Tanahun District, Nepal. Thesis submitted to Tribhuvan University, Institute ofForestry, Pokhara Campus, Pokhara.

Giri, B.K. 2009. Habitat suitability Mapping and Species Identification of Chiroptera: A case Study from Kaski District, Nepal. Thesis submitted to Tribhuvan University, Institute of Forestry, Pokhara Campus, Pokhara.

Malla, R. 2000. Diet Analysis of Hipposideros armiger and Rhinolophus pusillus (Microchiroptera) of Nagarjuna Cave. A thesis submitted to Central Department of Zoology Tribhuvan University in partial fulfillment of the requirement of the Masters degree of Science (M. Sc.) in Zoology.

Mickleburgh, S.P.,Hutson A.M. and Racey P.A.(Compiler) 1992. Old world Fruit Bats: An Action Plan for their Conservation. IUCN/ SSC. Chiroptera Specialist Group. IUCN, Gland, Switzerland.

Mickleburgh, S.P., Hutson, A.M. and Racey, P.A. 2002. A review of the global conservation status of bats. Oryx 36 (1): 18-34.

Srinivasulu, C. Racey, P.A. and Mistry, S. 2010. A key to the bats (Mammalia: Chiroptera) of South Asia. Journal of Threatened Taxa 2 (7): 1001-1076.

Thapa, S. 2010. An Updated Checklist of valid bat species of Nepal, Small Mammal MailBi- Annual Newsletter of CCINSA \& RISCINSA Volume 2, Number 1, Jan-Jun 2010, 16-17pp.

Thapa, S. and Thapa, A. 2010. A short note on chiropteran status from Kailash cave, Syangja district, Western Nepal. Lifescience Journo-Magazine, Vol. 2, Issue 1: 1-7 